Article

\title{
An Audit of Australian Bread with a Focus on Loaf Breads and Whole Grain
}

\author{
Sara Grafenauer* and Felicity Curtain \\ Grains \& Legumes Nutrition Council, Sydney, NSW 2060, Australia; contactus@glnc.org.au \\ * Correspondence: sarag@glnc.org.au; Tel.: +61-9394-8662
}

Received: 27 July 2018; Accepted: 14 August 2018; Published: 16 August 2018

\begin{abstract}
Bread is a vehicle for a range of nutrients within the Australian diet, but has been the target of negative press. The aim of this study was to examine bread products, particularly white, whole grain and gluten-free loaves, including nutrients, health claims and Health Star Rating (HSR). An audit of four supermarkets and a bakery franchise (2017) was compared with 2014 data. Median and range was calculated for whole grain content, dietary fibre, sodium, protein, carbohydrate and sugar. Of all breads $(n=456), 29 \%$ were eligible to make a whole grain claim with $27 \%$ very high in whole grain ( $\geq 24 \mathrm{~g}$ /serve), an $18 \%$ increase from 2014 . Within loaves $(n=243), 40 \%$ were at least a source of whole grain ( $\geq 8 \mathrm{~g}$ / serve), $79 \%$ were at least a source of dietary fibre, $54 \%$ met the sodium reformulation target ( $\leq 400 \mathrm{mg} / 100 \mathrm{~g}$ ), 78\% were a 'source' and 20\% were a 'good source' of protein (10 g/serve), and 97\% were low in sugar. Despite significant differences between loaves for all nutrients assessed, HSR did not differ between white and whole grain varieties. Compared to 2014, there were 20 fewer white loaves and 20 additional whole grain loaves which may assist more Australians achieve the $48 \mathrm{~g}$ whole grain daily target intake.
\end{abstract}

Keywords: bread; whole grain; wholemeal; dietary fibre; sodium; gluten free; carbohydrate; sugar; protein; health claim

\section{Introduction}

Bread is a staple food in many countries around the world and is one of the key products within the cereal and cereal products group of foods. It is a useful food vehicle for fortification of at-risk micronutrients in the Australian diet, specifically serving as a strategy to help reduce the incidence of Wernicke-Korsakoff syndrome [1] (via thiamin) and improve folate [2] and iodine status [3,4]. The National Nutrition and Physical Activity Survey (NNPAS), as part of the Australian Health Survey 2011-2013 [5], identified that within the bread category, plain, regular bread and bread rolls are consumed by $66 \%$ of Australians with a median consumption of $72 \mathrm{~g}$ (approximately two average slices) on the day prior to the NNPAS interview [5]. Most often, this was white bread (58\%) with mixed grain and wholemeal varieties accounting for 18\% [5]. Since 1995, the amount of bread consumed has decreased by $20 \mathrm{~g} /$ person/day [6].

Grain foods, including bread products, have been shown to provide a range of shortfall nutrients in the U.S. [7,8]; and from NNPAS, this group of foods are known to supply B vitamins, iron, calcium, magnesium, selenium, zinc and dietary fibre for Australians [9]. Bread is also a potential source of whole grain in the diet. Meta-analyses and systematic reviews of all-cause and cause-specific mortality are supportive of whole grains [10-12] and analyses of randomised clinical trials provide additional support indicating that whole grains produce reductions in low density lipoprotein (LDL) cholesterol, total cholesterol and percentage body fat compared to diets without them, and show improvements in postprandial glucose levels and glucose homeostasis [13-15]. Furthermore, there is a growing 
understanding that whole grains are more than just fibre [16], providing a range of micronutrients and other bioactive compounds with a variety of functions.

The Grains \& Legumes Nutrition Council (GLNC) led the development of the Code of Practice for Whole Grain Ingredient Content Claims (The Code) in Australia and New Zealand, and measures compliance with this code by conducting rolling category audits of grain foods. The Code, developed in 2013, provides guidance on the use of whole grain ingredient content claims with cut-off values of at least $8 \mathrm{~g}$ per manufacturer serve (contains whole grain), at least $16 \mathrm{~g}$ per serve (high in whole grain) and at least $24 \mathrm{~g}$ per serve (very high in whole grain) [17]. Food Standards Australia New Zealand (FSANZ) do not regulate claims describing the amount of whole grain in foods but define whole grain as the intact grain or the dehulled, ground, milled, cracked or flaked grain where the constituents-endosperm, germ and bran-are present in such proportions that represent the typical ratio of those fractions occurring in the whole cereal, and includes wholemeal [18]. The Code was designed to complement existing food standards and to assist consumers in meeting the $48 \mathrm{~g}$ Daily Target Intake (DTI). The whole grain DTI was determined by an expert round table $[19,20]$ and is based on the scientific evidence that people who eat at least 48 grams of whole grain each day are less likely to develop coronary heart disease [11] and this is consistent with the target used in the U.S. [21].

From NNPAS, the median daily whole grain intake was calculated at $21 \mathrm{~g}$ for adults [22] with only $31 \%$ meeting the $48 \mathrm{~g}$ DTI. This low level of whole grain consumption is not uncommon $[23,24]$ despite higher levels of consumption being related to lower risk for most non-communicable disease endpoints [25-28]. Therefore, there is need for clear labeling, marketing and increased awareness to assist individuals in making choices within this category, which may be associated with better health outcomes.

Despite bread's role in the diet and in providing key nutrients, over the last two decades it has often been the focus of criticism, regarding the sodium, added sugar and overall carbohydrate content due to health concerns and popular diet trends like low carbohydrate and gluten-free. Many consumers hold beliefs that breads are 'fattening' and cause bloating [29]. In addition to this, the Health Star Rating (HSR), the current front-of-pack nutrition communication tool used in Australia, does not utilise whole grain content as part of the algorithm calculating the number of stars a product can display. This potentially impacts the consumers' ability to differentiate between refined and whole grain products within this and other grain food categories.

The aim of this study was to examine the variety of bread products available, particularly loaves (white, whole grain and gluten free), including nutrients and health claims with a focus on whole grain content, dietary fibre, sodium, protein, carbohydrate and sugar and also the HSR.

\section{Materials and Methods}

An audit of bread was conducted using a recognised process for the collection of nutrient composition [30] from four major supermarkets in the Sydney Metropolitan area with the addition of a Bakery franchise (Bakers Delight ${ }^{\mathrm{TM}}$, Camberwell, Victoria, Australia) during September 2017. Permission to visit each of the local supermarkets was sought prior to the audit process, and consent was requested from the store manager to proceed on the day of the audit (Woolworths, Neutral Bay; Independent Grocers of Australia (IGA), Cremorne; Coles, Neutral Bay; Aldi, North Sydney). Photographs were taken with smartphones of all available products within each bread category. Auditors captured all sides of the packets and ensured inclusion of any writing or logos including front-of-pack, nutrition information, the nutrition information panel (NIP) and health claims. Bread products included in this audit comprised of bread loaves; rolls; sandwich alternatives including wraps, thins, Lebanese and pita bread; as well as flatbreads such as Turkish, ciabatta, Indian, foccacia and yiros. Bakery breakfast products such as fruit bread, brioche, English muffins, crumpets and pancakes were also included. Loaf breads were categorised into three main types of bread loaves for analysis (white, wholemeal/whole grain and gluten-free options). Products excluded from this audit comprised of the store's bakery goods section (in-store bakery), pizza bases, and bread sticks such as 
baguettes and breads containing added ingredients (e.g., olives and cheese). If products were sold out during the data collection period, auditors noted this and conducted an online search of the nutrition information on the manufacturer's website. Product data from Bakers Delight ${ }^{\mathrm{TM}}$ were taken from their website as there is no nutritional information or claims made on the packaging supplied to consumers.

The information obtained from the photographs was entered into a Microsoft ${ }^{\circledR}$ Excel $^{\circledR}$ spreadsheet (Version 2013, Redmond, Washington, USA). Information required for data entry included the NIP per serve and per $100 \mathrm{~g}$, the percent of whole grains, ingredients and health-related claims (Table 1) including whole grain, dietary fibre, sodium, protein, carbohydrate and sugar and front-of-pack information (HSR). Additionally, the number of products eligible to make nutrition claims was documented. The eligibility of providing a whole grain content claim was assessed in line with The Code. The total number of products eligible for a claim was noted as well as the percentage of these that were eligible for each level (contains whole grain, high in whole grain and very high in whole grain) of claim. If any products registered or unregistered made a whole grain or nutrient claim that was not compliant with The Code or were deemed misleading, they were entered into a whole grain compliance monitoring document for follow up by GLNC.

Table 1. Nutrition claims and reformulation target relevant for the bread category.

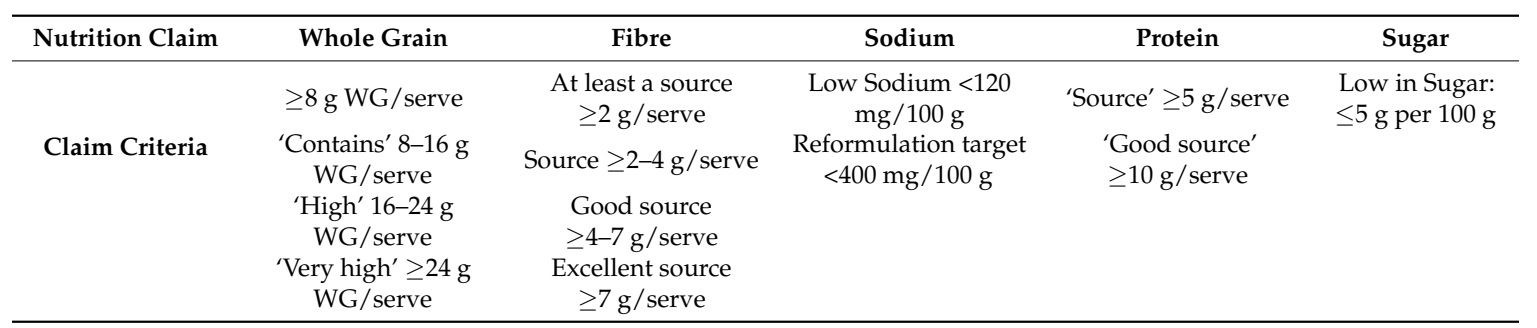

Data were cross-checked with manufacturer data and following data entry, results were independently checked by a second reviewer for any inconsistencies or errors. Results were compared with data from the bread audit conducted by GLNC in 2014 [31] regarding change in sodium content and the number of whole grain products. This audit utilised the same methods and quality processes as the current audit, and collected a similar number of loaf breads $(n=242)$ and total breads $(n=474)$ from the same supermarket locations.

\section{Statistics}

All data were checked for normality using Shapiro-Wilks (IBM SPSS ${ }^{\circledR}$, version 25.0, IBM Corp., Chicago, IL, USA). Kruskal-Wallis test (IBM SPSS ${ }^{\circledR}$, version 25.0, IBM Corp., Chicago, IL, USA) was used to compare differences in whole grain content and nutrients in loaf breads. Descriptive data was used to present the products meeting claimable amounts for whole grain, dietary fibre, the reformulation target for sodium, protein, sugar and HSR.

\section{Results}

Of 456 bread products in the total bread category, there were 243 loaves ( 80 white loaves, 141 whole grain loaves, 22 gluten-free loaves). The remaining bread category was made up of 53 rolls including burger buns and hot dog rolls (34 white rolls, 13 whole grain rolls, 6 gluten-free rolls), 73 sandwich alternatives (55 wraps, 3 sandwich thins, 11 Lebanese breads, 4 pita breads), 24 flatbreads (21 Turkish breads, 2 ciabatta breads, 1 Indian naan bread), and 63 bakery breakfast products ( 3 crumpets, 33 fruit breads, 4 English muffins, 10 pancakes \& pikelets, 9 brioche, and 4 bagels).

With the exception of protein, other nutrient data were not normally distributed. The whole grain content and key nutrients in loaf breads (white, whole grain and gluten-free) and in the total bread category are presented in Table 2 (median and range). A Kruskal-Wallis H test found a statistically significant difference between loaf breads in whole grain content $\left(X^{2}=13.385, p=0.001\right)$, dietary fibre 
$\left(X^{2}=43.307, p<0.0001\right)$, sodium $\left(X^{2}=19.019, p<0.0001\right)$, protein $\left(X^{2}=52.748, p<0.001\right)$, carbohydrate $\left(X^{2}=21.280, p<0.001\right)$ and sugar $\left(X^{2}=8.979, p=0.011\right)$. The percentage of products meeting the nutrition claims identified for the bread category are presented in Table 3. In summary, of all bread products, $29 \%$ were eligible to make a whole grain claim with $27 \%$ of bread products very high in whole grain ( $\geq 24 \mathrm{~g}$ /serve) (up from $18 \%$ in 2014). Within loaf breads $(n=243), 40 \%$ were at least a source of whole grain ( $\geq 8 \mathrm{~g} /$ serve), $79 \%$ were at least a 'source' of dietary fibre, $54 \%$ met the Australian Government's reformulation target of $\leq 400 \mathrm{mg} / 100 \mathrm{~g}$ sodium, $78 \%$ were a source of protein, $20 \%$ were a 'good source' of protein (10 g/serve), and the majority (97\%) were low in sugar.

Table 2. Whole grain content and key nutrients in loaf breads (white, whole grain and gluten-free) and in the total bread category.

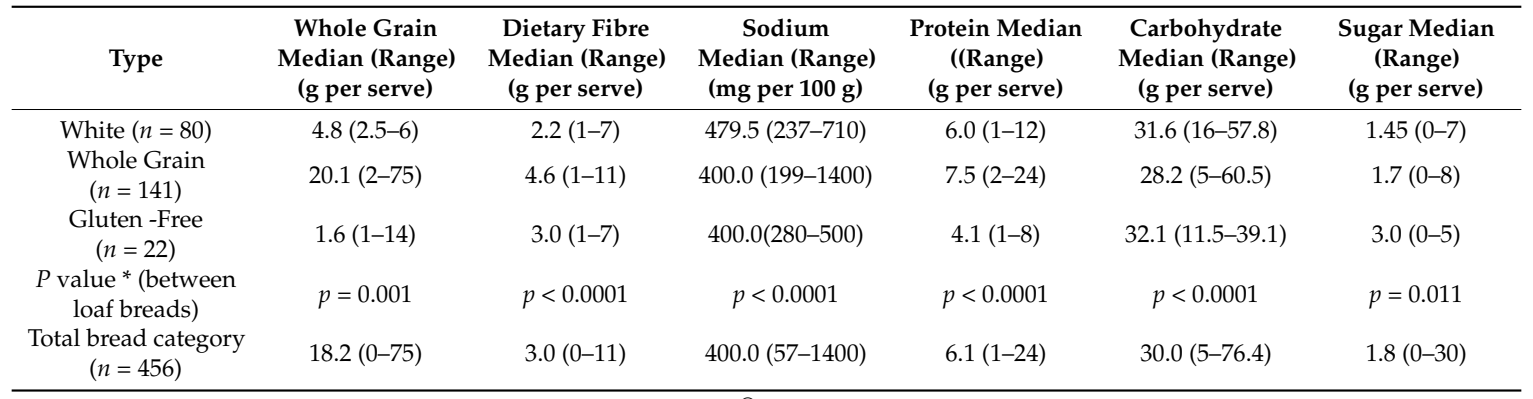

${ }^{*}$ Kruskal-Wallis test $(p<0.005)$ (IBM SPSS ${ }^{\circledR}$, version 25.0, IBM Corp., Chicago, IL, USA).

Table 3. Percentage of loaf breads and total bread meeting the claim criteria and sodium reformulation target.

\begin{tabular}{ccccc}
\hline Claim Criteria & $\begin{array}{c}\text { White } \\
(\boldsymbol{n}=\mathbf{8 0})\end{array}$ & $\begin{array}{c}\text { Whole Grain } \\
(\boldsymbol{n}=\mathbf{1 4 1})\end{array}$ & $\begin{array}{c}\text { Gluten-Free } \\
(\boldsymbol{n}=\mathbf{2 2})\end{array}$ & $\begin{array}{c}\text { Total Bread } \\
(\boldsymbol{n}=\mathbf{4 5 6})\end{array}$ \\
\hline Eligible for WG claim & 0 & 67 & 5 & 28 \\
Contains WG & 0 & 27 & 0 & 25 \\
High in WG & 0 & 21 & 0 & 22 \\
Very high in WG & 0 & 52 & 0 & 51 \\
At least a source of fibre & 62 & 89 & 81 & 68 \\
Source of fibre & 47 & 32 & 48 & 54 \\
Good Source of fibre & 15 & 47 & 24 & 8 \\
Excellent Source of fibre & 0 & 10 & 9 & 5 \\
Low in Sodium & 0 & 0 & 0 & 52 \\
Source of protein & 37 & 58 & 90 & 57 \\
Good source of protein & 73 & 65 & 0 & 12 \\
Low in sugar & 7 & 20 & 90 & 90 \\
\hline
\end{tabular}

The mean HSR for white loaves was only $1 / 2$ a star below that for whole grain varieties (3.7 versus 4.2) and for gluten-free loaves, a mean of 4 stars, possibly due to the lower protein content. The total number of bread loaves with a HSR was 40 , representing $28 \%$ of the audited products and four products in this audit displayed less than three stars. There was little change in the number of gluten-free products over time, with one less loaf in this audit and an increase in rolls from 2 to 6 products between 2014 and 2017.

\subsection{Whole Grain}

Whole grain sliced loaves, rolls and sandwich thins were the best source of whole grain within the bread category. Whole grain loaves were higher in fibre, protein and contained less carbohydrate and sugar than other loaf breads. No white rolls, gluten-free rolls or pita breads were eligible to make 
a whole grain claim. One gluten-free loaf could make a whole grain claim. One white sliced loaf was labeled as whole grain and contained a claimable amount of whole grain, so this product was included in the whole grain bread category. Seventy-nine products made an on-pack claim about whole grain, and these were mostly wholemeal bread loaves. Sixty additional products were eligible but did not make a whole grain claim and $17 \%$ of all bread products $(n=78)$ were not assessable for their whole grain content, as they did not provide the percentage of whole grain in the ingredients list. Compared to 2014, there were 20 fewer white loaves and 20 additional whole grain loaves available for purchase.

\subsection{Dietary Fibre}

Whole grain sliced loaves and rolls were the best source of dietary fibre within the total bread category with a median of $4.6 \mathrm{~g}$ per serve, or one sixth of the daily $30 \mathrm{~g}$ Adequate Intake [32]. The fibre content of white bread was less than half that of whole grain varieties. One product made a fibre claim and was ineligible to do so. No other issues of this type were found through this audit.

\subsection{Sodium}

More than half of all breads (237 products) met the Australian Government's reformulation target of $\leq 400 \mathrm{mg} / 100 \mathrm{~g}$ sodium [33]. Sodium content varied widely between 57 to $1400 \mathrm{mg}$ per $100 \mathrm{~g}$ in this audit with a median of $400 \mathrm{mg} / 100 \mathrm{~g}$ across all bread types from the total bread category. One bread a German Pumpernickel bread (Delba's ${ }^{\text {TM }}$, Delbrück, Germany) was the outlier with $1400 \mathrm{mg} / 100 \mathrm{~g}$. Just two products could claim low sodium $(<120 \mathrm{mg} / 100 \mathrm{~g})$. Gluten-free versions had the lowest levels of the loaves audited, with $90 \%$ meeting the reformulation target. Compared with the bread audit conducted by GLNC in 2014, the median sodium content for all breads is now $11 \%$ lower (450 mg/100 g, $n=467)$.

\subsection{Protein}

One in every five whole grain sliced loaves and $42 \%$ of flatbreads were a 'good source' of protein, offering at least $10 \mathrm{~g}$ per serve. Close to a quarter of white sliced loaves were a 'source' of protein, with at least $5 \mathrm{~g}$ per serve. Gluten-free sliced loaves and sandwich thins contained the least protein.

\subsection{Carbohydrate and Sugar}

Carbohydrate $(\mathrm{CHO})$ ranged from $5 \mathrm{~g} /$ serve to $76.4 \mathrm{~g} /$ serve in the total bread category with a median of $30 \mathrm{~g} /$ serve, typically two slices. Flatbreads contained the most $\mathrm{CHO}$ (mostly determined by the larger serving size of $114 \mathrm{~g}$ ) and Sandwich Thins were the lowest. Within loaves, there was a slight advantage in choosing whole grain varieties which were slightly lower in carbohydrate, with one product containing only $5 \mathrm{~g}$ /serve. Nearly all breads captured (90\%) were considered low in sugar ( $\leq 5 \mathrm{~g} / 100 \mathrm{~g})$. Bakery breakfast products were the exception, and included sweet breads like brioche, pancakes/pikelets and fruit bread, these had an average of $10 \mathrm{~g} / \mathrm{serve}$.

\section{Discussion}

There are important findings from this research to guide product development within industry, and correct some of the misinformation regarding bread, particularly for nutrition professionals assisting Australians to achieve the $48 \mathrm{~g}$ DTI for whole grains. Of all bread products examined, one-third were eligible to make a whole grain claim, with $27 \%$ of bread products very high in whole grain ( $\geq 24 \mathrm{~g} /$ serve) and many of these easily providing $100 \%$ of the DTI for whole grain. Loaf breads were the most frequently consumed type of bread, so the fact that $79 \%$ of loaves were at least a source of fibre and an even higher proportion (40\%) were at least a source of whole grain $(\geq 8 \mathrm{~g} / \mathrm{serve})$ is reassuring. Importantly, whole grain varieties within the category of loaf breads have increased over time, seemingly replacing white loaves. The reason for manufacturers of 60 eligible products 
not claiming whole grain content is unclear, and is an opportunity within the current market as this category expands.

In relation to whole grain in bread, despite the uptake by industry, consumption studies suggest that only about one-third of Australians meet the recommended DTI of $48 \mathrm{~g}$ [22]. The Australian Dietary Guidelines suggest 'mostly whole grain' [34], encouraging consumption, but at the same time respecting the value of core, refined grain foods in diets. However, it is recognised that more specific guidance is needed to achieve higher quality diets for disease prevention [35]. Consumption of whole grain foods was calculated from the NNPAS at $21 \mathrm{~g} /$ day for adults (19-85 year) and $17 \mathrm{~g} /$ day for children (2-18 year) [22] and a similar level was derived from the most recent consumption research commissioned by GLNC $(n=1121)$ at $26 \mathrm{~g} /$ day (9-70 year) and $16 \mathrm{~g} /$ day for children [36]. These results are similar to those gathered in the UK [24], USA [23], Ireland [37] and Singapore [38] while other countries, such as France [39], Italy [40] and Malaysia [41] have far lower intakes. Scandinavian countries have recently increased intakes, in particular Denmark, who has successfully promoted whole grains, increasing consumption from $33 \mathrm{~g} /$ day (from 2000-2004) to $55 \mathrm{~g} /$ day (in 2011-2014) [42]. On average, bread products have been shown to provide $20 \%$ of the whole grain Daily Target Intake (DTI), with 40\% from cereals and a further 19\% from 'other breads' like tortillas [36].

Bread has been the target of negative press, despite being a vehicle for a range of key nutrients within the Australian diet. This includes nutrients of concern such as dietary fibre, iron and thiamine but also folate and iodine, the latter two being mandatory fortificants added to bread-making flour since 2009. Importantly, following folic acid fortification in Australia, there was a statistically significant $14.4 \%$ decrease in the rate of neural tube defects (NTD) across the population (excluding Victoria, the Australian Capital Territory and Tasmania where insufficient data was available) [6]. This reduction was predicted prior to mandating fortification and was based on consumption of three slices of bread per day [6], plus other measures (such as supplements) within at risk groups. The impact of folic acid fortification was even greater among Aboriginal and Torres Strait Islander women with a $72.2 \%$ reduction of NTD [6].

In the case of iodine, the Australian population is now reportedly consuming sufficient iodine to address the recent re-emergence of mild iodine deficiency at the population level. However, studies in South Australia and Western Australia indicate that pregnant and breastfeeding women may still require supplements and iodised salt $[3,43]$. In New Zealand there have been more modest improvements and some target groups remain at risk of mild iodine deficiency [6]. For a successful fortification program, consumption of the fortified food needs to remain fairly stable. As less bread is being consumed in Australia, the nutrients from this staple may need to be provided by other foods or drinks [44,45]. Whereas National data indicated a $20 \mathrm{~g}$ decline in bread consumption [5], GLNC data show a larger reduction [46], from $124.5 \mathrm{~g}$ in 2014 down to $66 \mathrm{~g}$ in 2017. A study of cereal foods from Western Australia also found a decline in intake over the same period of time (1995 through to 2012) and concluded there were misperceptions as to the adequacy of intake of grain foods, specifically whole grains [35].

More than half (54\%) of all loaves audited met the Australian Government's reformulation target of $\leq 400 \mathrm{mg} / 100 \mathrm{~g}$ for sodium and two products were able to claim low sodium. All Lebanese and sandwich thins contained $\leq 400 \mathrm{mg} / 100 \mathrm{~g}$, and consumption of these products is increasing [46]. Sodium is a current focus within the public health domain [47] internationally and in Australia, with targets for sodium in bread expected to be reduced to $\leq 380 \mathrm{mg} / 100 \mathrm{~g}$ as part of the Healthy Food Partnership reformulation proposal. However, reformulation needs to be balanced against the role that bread plays in supplying fortificants like iodine. Salt in bread controls the yeast through fermentation and stabilises gluten [44] and, therefore, impacts on how the dough handles as it moves through modern production lines. Sodium also influences shelf life and the final texture and flavour of the bread $[48,49]$. However, there is scope for sodium reduction, and in bread, $300 \mathrm{mg} / 100 \mathrm{~g}$ has been tested [47]. The results from this audit are comparable to Trevena et al. [49] who found that mean sodium from approximately 150 bread varieties was $415 \mathrm{mg} / 100 \mathrm{~g}$ in 2013, 9\% lower than an audit 
conducted in 2010, where 67\% met the reformulation target. From the GLNC 2014 audit, median sodium content of $450 \mathrm{mg} / 100 \mathrm{~g}(n=467)$ was reduced to $400 \mathrm{mg}$ in 2017 . This was an $11 \%$ reduction with just over half of bread varieties meeting the current sodium target. Lindberg et al. [50] also showed improvements with $86 \%$ meeting the target in 2015 , an improvement from $28 \%$ at baseline when the sodium target was introduced [51].

Close to one in every five loaves of whole grain bread assessed was considered a 'good source' of protein, with at least $10 \mathrm{~g}$ per serve-the same amount found in a glass of milk or two boiled eggs. Almost three quarters (73\%) of white sliced loaves were a 'source' of protein, with at least 5 g per serve. Consumers are interested in plant proteins, and they may not consider bread as a potential source. In addition to grains and seeds, ingredients like legumes and legume flours are being added to bread ( $5 \%$ of all breads in this audit) in the form of lentils, lupin bran, broad bean flour, besan flour, mung beans and soy beans in various forms (kibbled and as flour). Although the evidence supports the plant protein trend in terms of health, particularly cardiometabolic health, the literature supports a balanced view which includes amounts of animal protein as per current dietary guidelines [52]. However, plant protein is a platform that is being used by some manufacturers to promote higher protein content via pack messages.

There is consumer concern about the added sugar in bread and this was one of the top four reasons Australians reportedly avoided bread in 2017 [46]. Sugar is added in small amounts of 1-2\% to bread to accelerate processes, produce an attractive crust colour and help tenderize bread [53]. In excess, sugar weakens the gluten network by competing for water [54]. From this audit, the majority $(89 \%)$ of loaves were low in sugar (less than $5 \mathrm{~g} / 100 \mathrm{~g}$ ), and this figure includes bakery breakfast products which contain dried fruit. When considering sliced loaves alone, $92 \%$ were low in sugar. Added sugar in the food supply is a current issue in Australia as labels on packaged foods and drinks do not provide a breakdown of intrinsic and added sugar and this may be a barrier for consumers in making informed choices.

Despite the apparent trend in gluten-free and wheat-free diets over the last several years and the expansion of these products within the mainstream food supply [55,56], there was little difference within the bread category in the number of sliced gluten-free loaves or rolls over time demonstrated by this audit. By excluding in-store bakery and limiting our analysis to loaf breads, some products may have been omitted from the gluten-free category that have been included in analyses by other authors, for example, Wu et al. (2015) [57] who analysed 54 gluten-free bread products. Importantly, there may be a perception among consumers that gluten-free is a healthier choice, but several studies support the opposite conclusion [56,57] with unfavourable changes to the microbiome and no impact on inflammatory markers $[58,59]$. Lower nutrient intakes, particularly lower protein and whole grain content were apparent from this study and others [56]; however, gluten-free loaves tended to be lower in sodium than white breads, with $90 \%$ meeting the reformulation target.

This study benefits from having a perspective of the total bread category, while the analysis focuses on just loaf breads. However, there are limitations as it is difficult to estimate the total bread market with accuracy due to the contribution of small, local bakeries and supermarket in-store bakeries to bread consumption. Specifically, exclusion of in-store bakeries may have limited the number of gluten-free products included compared to other studies [57]. Regarding the data collected, it is not mandatory to report the dietary fibre in the NIP unless there is an on-pack claim. Similarly, reporting whole grain is voluntary, so whole grain content (as a percentage) may not always be declared and as such, there may be missing data. We did not conduct our own analysis of nutrient content and were reliant on manufacturer data, this is an unavoidable limitation. All care was taken to ensure the quality of the data and limit error in tabulation through quality checking by an independent reviewer and packaging photographs assisted with this process. 


\section{Conclusions}

There has been a change in the way bread is used in diets. Previously, a common inclusion at each meal of the day, to the current day, where some consumers are actively avoiding bread or reducing consumption. This audit highlights some of the key nutrients in breads, compliance with reformulation targets and the change in the market toward increasing whole grain and high fibre varieties. Continued clear messaging on pack by food industry, combined with consistent messaging from healthcare professionals, government bodies and Dietary Guidelines about the value of bread in the diet pattern is needed. This is crucial if bread is to continue as an effective food vehicle for broad fortification programs. However, greater efforts may be required to change the negative attitudes to carbohydrate foods in general and support promotion of core foods in a positive manner. Communication tools that reflect the value of grain foods and whole grain food choices in particular, are needed to encourage consumers to make better food choices. In this respect, the Code of Practice for Whole Grain Ingredient Content Claims provides a model for regulation and permitted on-pack claims. The potential inclusion of whole grain as part of the Health Star Rating system is also an opportunity that may assist Australians in reaching the $48 \mathrm{~g}$ whole grain target, with potential positive health outcomes.

Author Contributions: Conceptualization, S.G. and F.C.; Formal Analysis, F.C.; Writing-Original Draft Preparation, S.G.; Writing-Review \& Editing, F.C.

Funding: This research received no external funding but was supported by the Grains \& Legumes Nutrition Council, a not-for-profit charity.

Acknowledgments: Sharon Liang and Sarah Miller, Student Dietitians from the University of Newcastle, Newcastle, NSW, were involved in all data collection as part of their university studies. Thanks to Eleanor Beck, Alex Locke and Joanna Russell for providing comments for this manuscript.

Conflicts of Interest: The authors are employed by the Grains \& Legumes Nutrition Council, a not-for-profit charity.

\section{References}

1. Harper, C.G.; Sheedy, D.L.; Lara, A.I.; Garrick, T.M.; Hilton, J.M.; Raisanen, J. Prevalence of wernicke-korsakoff syndrome in Australia: Has thiamine fortification made a difference? Med. J. Aust. 1998, 168, 542-545. [PubMed]

2. Bower, C.; Maxwell, S.; Hickling, S.; D'Antoine, H.; O'Leary, P. Folate status in aboriginal people before and after mandatory fortification of flour for bread-making in Australia. Aust. N. Z. J. Obstet. Gynaecol. 2016, 56, 233-237. [CrossRef] [PubMed]

3. Condo, D.; Huyhn, D.; Anderson, A.J.; Skeaff, S.; Ryan, P.; Makrides, M.; Mühlhaüsler, B.S.; Zhou, S.J. Iodine status of pregnant women in south Australia after mandatory iodine fortification of bread and the recommendation for iodine supplementation. Matern. Child. Nutr. 2017, 13, e12410. [CrossRef] [PubMed]

4. Charlton, K.; Probst, Y.; Kiene, G. Dietary Iodine intake of the Australian population after introduction of a mandatory iodine fortification programme. Nutrients 2016, 8, 701. [CrossRef] [PubMed]

5. Australian Bureau of Statistics. Australian Health Survey: Nutrition First Results-Foods and Nutrients, 2011-12: Cereals and Cereal Products. 2014. Available online: http://www.abs.gov.au/ausstats/abs@ .nsf/Lookup/by\%20Subject/4364.0.55.007 2011-12 Main\%20Features Cereals\%20and\%20cereal\% 20products 720 (accessed on 23 July 2018).

6. Australian Institute of Health and Welfare. Monitoring the health impacts of mandatory folic acid and iodine fortification. 2016. Available online: https://www.aihw.gov.au/reports/food-nutrition/monitoring-healthimpacts-of-mandatory-folic-acid/contents/table-of-contents (accessed on 23 July 2018).

7. Papanikolaou, Y.; Fulgoni, V. Certain grain foods can be meaningful contributors to nutrient density in the diets of U.S. children and adolescents: Data from the national health and nutrition examination survey, 2009-2012. Nutrients 2017, 9, 160. [CrossRef] [PubMed]

8. Papanikolaou, Y.; Fulgoni, V.L. Grain foods are contributors of nutrient density for American adults and help close nutrient recommendation gaps: Data from the national health and nutrition examination survey, 2009-2012. Nutrients 2017, 9, 873. [CrossRef] [PubMed] 
9. ABS Australian health survey: Nutrition first results-foods and nutrients, 2011-12. Available online: http:/ / www.abs.gov.au/ausstats/abs@.nsf/Lookup/by\%20Subject/4364.0.55.007 2011-12 Main\% 20Features Key\%20Findings 1 (accessed on 23 July 2018).

10. Aune, D.; Keum, N.; Giovannucci, E.; Fadnes, L.T.; Boffetta, P.; Greenwood, D.C.; Tonstad, S.; Vatten, L.J.; Riboli, E.; Norat, T. Whole grain consumption and risk of cardiovascular disease, cancer, and all cause and cause specific mortality: systematic review and dose-response meta-analysis of prospective studies. Br. Med. J. 2016, 353, i2716. [CrossRef] [PubMed]

11. Zong, G.; Gao, A.; Hu, F.B.; Sun, Q. Whole grain intake and mortality from all causes, cardiovascular disease, and cancer: a meta-analysis of prospective cohort studies. Circulation 2016, 133, 2370-2380. [CrossRef] [PubMed]

12. Zhang, B.; Zhao, Q.; Guo, W.; Bao, W.; Wang, X. Association of whole grain intake with all-cause, cardiovascular, and cancer mortality: A systematic review and dose-response meta-analysis from prospective cohort studies. Eur. J. Clin. Nutr. 2018, 72, 57-65. [CrossRef] [PubMed]

13. Hollaender, P.L.; Ross, A.B.; Kristensen, M. Whole-grain and blood lipid changes in apparently healthy adults: A systematic review and meta-analysis of randomized controlled studies. Am. J. Clin. Nutr. 2015, 102, 556-572. [CrossRef] [PubMed]

14. Marventano, S.; Vetrani, C.; Vitale, M.; Godos, J.; Riccardi, G.; Grosso, G. Whole grain intake and glycaemic control in healthy subjects: A systematic review and meta-analysis of randomized controlled trials. Nutrients 2017, 9, 769. [CrossRef] [PubMed]

15. Pol, K.; Christensen, R.; Bartels, E.M.; Raben, A.; Tetens, I.; Kristensen, M. Whole grain and body weight changes in apparently healthy adults: A systematic review and meta-analysis of randomized controlled studies. Am. J. Clin. Nutr. 2013, 98, 872-884. [CrossRef] [PubMed]

16. Fardet, A. New hypotheses for the health-protective mechanisms of whole-grain cereals: What is beyond fibre? Nutr. Res. Rev. 2010, 23, 65-134. [CrossRef] [PubMed]

17. GLNC. Code of practice for whole grain ingredient content claims. Available online: http://www.glnc.org. au/codeofpractice/ (accessed on 23 July 2018).

18. FSANZ. Australia New Zealand Food Standards Code. Standard 2.1.1.-Cereals and Cereal Products; Food Standards Australia New Zealand: Canberra, Australia. Available online: https:/ / www.legislation.gov.au/ Details/F2015L00420 (accessed on 9 August 2018).

19. Griffiths, T. Towards an Australian 'daily target intake' for wholegrains. Food Aust. 2007, 59, 600-601.

20. Griffiths, T.; Nestel, P. Developing a target for daily wholegrain intake for Australians. Food Aust. 2006, 58, 431-433.

21. U.S. Department of health and human services and U.S. department of agriculture 2015-2020 dietary guidelines for Americans. Available online: https://health.gov/dietaryguidelines/2015/guidelines/ (accessed on 9 August 2018).

22. Galea, L.; Beck, E.; Probst, Y.; Cashman, C. Whole grain intake of Australians estimates from a cross-sectional analysis of dietary intake data from the 2011-13 Australian health survey. Public Health Nutr. 2017, 20, 2166-2172. [CrossRef] [PubMed]

23. Albertson, A.M.; Reicks, M.; Joshi, N.; Gugger, C.K. Whole grain consumption trends and associations with body weight measures in the United States: Results from the cross sectional national health and nutrition examination survey 2001-2012. Nutr. J. 2016, 15, 8. [CrossRef] [PubMed]

24. Mann, K.D.; Pearce, M.S.; McKevith, B.; Thielecke, F.; Seal, C.J. Low whole grain intake in the UK: results from the national diet and nutrition survey rolling programme 2008-2011. Br. J. Nutr. 2015, 113, 1643-1651. [CrossRef] [PubMed]

25. Ley, S.H.; Hamdy, O.; Mohan, V.; Hu, F.B. Prevention and Management of Type 2 Diabetes: Dietary components and nutritional strategies. Lancet 2014, 383, 1999-2007. [CrossRef]

26. Bechthold, A.; Boeing, H.; Schwedhelm, C.; Hoffmna, G.; Knuppel, S.; Iqbal, K.; De Henauw, S.; Michels, N.; Devleesschauwer, B.; Schlesinger, S.; et al. Food groups and risk of coronary heart disease, stroke, and heart failure: A systematic review and dose-response meta-analysis of prospective studies. Crit. Rev. Food Sci. Nutr. 2017, 17, 1-20. [CrossRef] [PubMed] 
27. World Cancer Research Fund; American Institute for Cancer Research. Diet, nutrition, physical activity and cancer: a global perspective. continuous update project expert report 2018. Available online: http: / / www.aicr.org/continuous-update-project/reports/colorectal-cancer-2017-report.pdf (accessed on 23 July 2018).

28. Mozaffarian, D. Dietary and policy priorities for cardiovascular disease, diabetes, and obesity: A comprehensive review. Circulation 2016, 133, 187-225. [CrossRef] [PubMed]

29. Robinson, E.; Chambers, L. The challenge of increasing wholegrain intake in the UK. Nutr. Bull. 2018, 43, 135-146. [CrossRef]

30. Dunford, E.; Webster, J.; Metzler, A.; Czernichow, S.; Mhurchu, C.N.; Wolmarans, P.; Snowdon, W.; L'Abbe, M.; Li, N.; Maulik, P.K.; et al. International collaborative project to compare and monitor the nutritional composition of processed foods. Eur. J. Prev. Cardiol. 2012, 19, 1326-1332. [CrossRef] [PubMed]

31. GLNC. FY14 Grains and Legumes Product Audit; Grains \& Legumes Nutrition Council: Sydney, Australia, 2014; Unpublished work.

32. NHMRC. Nutrient reference values for Australia and New Zealand-Dietary fibre. Available online: https: / /www.nrv.gov.au/nutrients / dietary-fibre (accessed on 9 August 2018).

33. Department of Health. Australian Government Healthy Food Partnership: Food Category Targets and Action Plans-Bread. Available online: http://www.health.gov.au/internet/main/publishing.nsf/Content/bread (accessed on 9 August 2018).

34. National Health and Medical Research Council. Australian dietary guidelines: Providing the scientific evidence for healthier Australian diets. 2013. Available online: https:/ /www.nhmrc.gov.au/_files_nhmrc/ file/publications/n55_australian_dietary_guidelines1.pdf (accessed on 23 July 2018).

35. Pollard, C.M.; Pulker, C.E.; Meng, X.; Scott, J.A.; Denham, F.C.; Solah, V.A.; Kerr, D.A. Consumer attitudes and misperceptions associated with trends in self-reported cereal foods consumption: Cross-sectional study of western Australian adults, 1995 to 2012. BMC Public Health 2017, 17, 597. [CrossRef] [PubMed]

36. Suthers, R. Whole Grain Consumption in Australia: Intake, Demographics, Barriers and Facilitators; University of Wollongong: Wollongong, Australia, 2017.

37. O’Donovan, C.B.; Devlin, N.F.; Buffini, M.; Walton, J.; Flynn, A.; Gibney, M.J.; Nugent, A.P.; McNulty, B.A. Whole grain intakes in Irish adults: findings from the national adults nutrition survey (NANS). Eur. J. Nutr. 2018. [CrossRef] [PubMed]

38. Neo, J.E.; Binte Mohamed Salleh, S.; Toh, Y.X.; How, K.Y.L.; Tee, M.; Mann, K.; Hopkins, S.; Thielecke, F.; Seal, C.J.; Brownlee, I.A. Whole-grain food consumption in Singaporean children aged 6-12 years. J. Nutr. Sci. 2016, 5, e33. [CrossRef] [PubMed]

39. Bellisle, F.; Hébel, P.; Colin, J.; Reyé, B.; Hopkins, S. Consumption of whole grains in French children, adolescents and adults. Br. J. Nutr. 2014, 112, 1674-1684. [CrossRef] [PubMed]

40. Sette, S.; D’Addezio, L.; Piccinelli, R.; Hopkins, S.; Le Donne, C.; Ferrari, M.; Mistura, L.; Turrini, A. Intakes of whole grain in an Italian sample of children, adolescents and adults. Eur. J. Nutr. 2017, 56, 521-533. [CrossRef] [PubMed]

41. Norimah, A.K.; Koo, H.C.; Jan, J.M.H.; Nasir, M.T.M.; Tan, S.Y.; Appukutty, M.; Nurliyana, A.R.; Thielecke, F.; Hopkins, S.; Ong, M.K.; et al. Whole grain intakes in the diets of malaysian children and adolescents-findings from the mybreakfast study. PLOS ONE 2015, 10. [CrossRef]

42. Mejborn, H.; Ygil, K.H.; Fagt, S. Wholegrain intake of danes 2011-2012. Available online: http:/ / www.food.dtu.dk/english/- / media/Institutter/Foedevareinstituttet/Publikationer /Pub2013/Rapport_Fuldkornsindtag_11-12_UK.ashx?la=da (accessed on 23 July 2018).

43. Jorgensen, A.; O'Leary, P.; James, I.; Skeaff, S.; Sherriff, J. Assessment of breast milk iodine concentrations in lactating women in western Australia. Nutrients 2016, 8, 699. [CrossRef] [PubMed]

44. O'Connor, Á. Bread consumption in the UK: What are the main attitudinal factors affecting current intake and its place in a healthy diet? Nutr. Bull. 2012, 37, 368-379. [CrossRef]

45. Edmonds, J.; McLean, R.; Williams, S.; Skeaff, S. Urinary iodine concentration of New Zealand adults improves with mandatory fortification of bread with iodised salt but not to predicted levels. Eur. J. Nutr. 2016, 55, 1201-1212. [CrossRef] [PubMed]

46. GLNC. 2017 Australian Grains and Legumes Consumption and Attitudinal Report; Grains \& Legumes Nutrition Council: North Sydney, Australia, 2017; Unpublished work. 
47. McMahon, E.; Webster, J.; Brimblecombe, J. Effect of 25\% sodium reduction on sales of a top selling bread in remote indigenous Australian community stores: A controlled intervention trial. Nutrients 2017, 9, 214. [CrossRef] [PubMed]

48. Munday, H.S.; Bagley, L. The contribution of food science to nutrition science through reformulation in the last 50 years and into the future. Nutr. Bull. 2017, 42,321-330. [CrossRef]

49. Trevena, H.; Neal, B.; Dunford, E.; Wu, J. An evaluation of the effects of the Australian food and health dialogue targets on the sodium content of bread, Breakfast Cereals and Processed Meats. Nutrients 2014, 6, 3802. [CrossRef] [PubMed]

50. Lindberg, R.; Nichols, T.; Yam, C. The healthy eating agenda in Australia. is salt a priority for manufacturers? Nutrients 2017, 9, 881. [CrossRef] [PubMed]

51. National heart foundation of Australia report on the evaluation of the nine food categories for which reformulation targets were set under the food and health dialogue. Available online: https: / / www.health.gov.au/internet/main/publishing.nsf/Content/7BD47FA4705160A6CA25800C008088B9/ \$File/Healthy\%20Food\%20Partnership\%20Evaluation\%20Report_Heart\%20Foundation.pdf (accessed on 23 July 2018).

52. Petersen, K.S.; Flock, M.R.; Richter, C.K.; Mukherjea, R.; Slavin, J.L.; Kris-Etherton, P.M. Healthy dietary patterns for preventing cardiometabolic disease: The role of plant-based foods and animal products. Curr. Dev. Nutr. 2017, 1, 1-7. [CrossRef] [PubMed]

53. Trinh, L.; Campbell, G.M.; Martin, P.J. Scaling down bread production for quality assessment using a breadmaker: Are results from a breadmaker representative of other breadmaking methods? Food Bioprod. Process. 2016, 100, 54-60. [CrossRef]

54. McGee, H. McGee on Food and Cooking, 2nd ed.; Simon \& Schuster: New York City, NY, USA, 2004; pp. 516-550, ISBN 9780684800011.

55. Golley, S.; Corsini, N.; Topping, D.; Morell, M.; Mohr, P. Motivations for avoiding wheat consumption in australia: Results from a population survey. Public Health Nutr. 2015, 18, 490-499. [CrossRef] [PubMed]

56. Morreale, F.; Angelino, D.; Pellegrini, N. Designing a score-based method for the evaluation of the nutritional quality of the gluten-free bakery products and their gluten-containing counterparts. Plant Foods Hum. Nutr. 2018, 73, 154-159. [CrossRef] [PubMed]

57. Wu, J.H.; Neal, B.; Trevena, H.; Crino, M.; Stuart-Smith, W.; Faulkner-Hogg, K.; Yu Louie, J.C.; Dunford, E. Are gluten-free foods healthier than non-gluten-free foods? An evaluation of supermarket products in Australia. Br. J. Nutr. 2015, 114, 448-454. [CrossRef] [PubMed]

58. Shepherd, S.J.; Gibson, P.R. Nutritional inadequacies of the gluten-free diet in both recently-diagnosed and long-term patients with coeliac disease. J. Hum. Nutr. Diet. 2013, 26, 349-358. [CrossRef] [PubMed]

59. Bonder, M.; Tigchelaar, E.F.; Cai, X.H.; Trynka, G.; Cenit, M.C.; Hrdlickova, B.; Zhong, H.Z.; Vatanen, T.; Gevers, D.; Wijmenga, C.; et al. The influence of a short-term gluten-free diet on the human gut microbiome. Genome Med. 2016, 8, 1-11. [CrossRef] [PubMed]

(C) 2018 by the authors. Licensee MDPI, Basel, Switzerland. This article is an open access article distributed under the terms and conditions of the Creative Commons Attribution (CC BY) license (http:/ / creativecommons.org/licenses/by/4.0/). 